\title{
SOSIO ANTROPOLOGI GIZI DAN KESEHATAN
}

\author{
YUSNIAR TIKSAH
}

( 70200121112 )

\author{
PROGRAM STUDI KESEHATAN MASYARAKAT \\ FAKULTAS KEDOKTERAN DAN ILMU KESEHATAN \\ UNIVERSITAS ISLAM NEGERI ALAUDDIN MAKASSAR
}

\section{PENGERTIAN SOSIOLOGI DAN ANTROPOLOGI}

Sosiologi yaitu ilmu yang mempelajari tentang hidup, hidup bersama dengan masyarakat sedangkan Antropologi ilmu yang mempelajari tentang manusia, pentingnya pendekatan suatu budaya. Antropos (manusia) dan Tropos (ilmu).

Antropologi mempunyai pandangan tentang pentingnya pendekatan budaya. Budaya merupakan pedoman individual sebagai anggota masyarakat dan bagaimana cara memandang dunia, bagaimana cara mengungkapkan emosionalnya dan bagaimana berhubungan dengan orang lain, kekuatan super natural atau Tuhan serta lingkungan alamnya.

Pada dasarnya perhatian antropologi yang paling awal adalah mengenai ciri-ciri dan sifat masyarakat: bagaimana manusia berhubungan satu dengan yang lain,dan bagaimana dan mengapa masyarakat berubah sepanjang waktu.

Kebanyakan antropolog sependapat bahwa antropologi muncul sebagai cabang keilmuan yang jelas batasannya pada sekitar pertengahan abad ke-19, tat kala perhatian orang pada evolusi manusia berkembang. Antropologi sebagai disiplin akademik dimulai tidak lama setelah itu, ketika pengangkatan pertama antropolog pofesional di universitas, museum dan kantor-kantor pemerintahan. Namun tidak adakeraguan bahwa gagasan antropologi sudah jauh sebelumnya (Herlina,2017).

Sosiologi adalah ilmu yang memisatkan perhatian pada segi-segi kemasyarakatan yang bersifat umum dan berusaha untuk mendapatkan pola-pola umum kemasyarakatan.

- Kebudayaan yaitu sebuah sistem gagasan, tindakan \& hasil yang diperoleh/dimiliki dalam proses pembelajaran.

- Kegunaan antropologi budaya untuk mengetahui PHBS manusia kemudian dikaitkan dengan pencegahan.

\section{POLA BUDAYA TERHADAP MAKANAN}

Berdasarkan batasan demikian maka dapat dikatakan bahwa makanan atau kebiasaan makan merupakan suatu produk budaya yang berhubungan dengan sistim tingkah laku dan tindakan yang terpola (sistim sosial) dari suatu komonitas masyarakat tertentu. Sedangkan makanan yang merupakan produk pangan sangat tergantung dari faktor pertanian di daerah tersebut dan merupakan produk dari budaya juga. 
Dengan demikian pengaruh budaya terhadap pangan atau makanan sangat tergantung kepada sistim sosial kemasyarakatan dan merupakan hak asasi yang paling dasar,maka pangan/makanan harus berada didalam kendali kebudayaan itu sendiri. Beberapa pengaruh budaya terhadap pangan/makanan adalah: Adanya bermacam jenis menu makanan dari setiap komunitas etnis masyarakat dalam mengolah suatu jenis hidangan makanan karena perbedaan bahan dasar/adonan dalam proses pembuatan;contoh: orang Jawa ada jenis menu makanan berasal dari kedele, orang Timor jenis menu makanan lebih banyak berasal dari jagung dan orang Ambon jenis menu makanan berasal dari sagu. Demikian juga orang Sulawesi menu makanan beragam yakni berasal dari beras, jagung dan sagu. Adanya perbedaan pola makan/konsumsi/makanan pokok dari setiap suku/etnis ; Contoh : orang Timor pola makan lebih kepada jagung, orang Jawa pola makan lebih kepada beras. Adanya perbedaan cita-rasa, aroma, warna dan bentuk fisik makanan dari setiap suku-etnis; Contoh: makanan orang Padang cita rasanya pedis, orang Jawa makananya manis dan orang Timor makanannya selalu yang asin. Adanya bermacam jenis nama dari makanan tersebut atau makanan khas berbeda untuk setiap daerah; contoh: Soto Makasar berasal dari daerah Makasar Sulawesi Selatan, Jagung "Bose" dari daerah Timor-Nusa Tenggara Timur, contoh lain dari daerah Maluku adalah sagu lempe yang biasa digunakan untuk snack dan lebih umum biasa digunakan sebagai behanoleh-oleh.

\section{SISTEM BUDAYA TERHADAP MAKANAN}

Sitem Budaya Terhadap Makanan Berbagai sistem budaya memberikan peranan dan nilai yang berbeda- beda terhadap makanan, misalnya bahan-bahan makanan tertentu oleh suatu budaya masyarakat dapat dianggap tabu atau bersifat pantangan untuk dikonsumsi karena alasan sakral tertentu atau sistim budaya yang terkait didalamnya. Disamping itu ada jenis makanan tertentu yang dinilai dari segi ekonomi maupun social sangat tinggi eksistensinya tetapi karena mempunyai peranan yang penting dalam hidangan makanan pada sesuatu perayaan yang berkaitan dengan kepercayaan masyarakat tertentu maka hidangan makanan itu tidak diperbolehkan untuk dikonsumsinya bagi golongan masyarakattersebut.

Kasus yang terjadi pada sistem budaya adalah sering terjadi pada masyarakat diperkotaan yang mempunyai gaya hidup budaya yang tingkat kesibukannya sangat tinggi karena alasan pekerjaan. Contohnya; pada ibu-ibu di daerah perkotaan yang kurang dan tidak sering menyusui bayinya dengan Air Susu Ibu (ASI) setelah melahirkan tetapi hanya diberikan formula susu bayi instant. Padahal kita tahu bahwa ASI sangat penting untuk pertumbuhan dan perkembangan fisik bayi. Selanjutnya gaya hidup mereka yang berasal dari golongan ekonomi atas (masyarakat elite kota), dalam hal makanan sering mengkonsumsi makanan yang berasal dari produk luar negeri atau makanan instant lainnya karena soal gengsi.

Sistem akan memberikan budaya terhadap makanan

1. Sifat makanan (larangan makanan tertentu), misalnyakelor

2. Hidangan makanan, misalnya upacaraadat

3. Mengonsumsi makanan dalam keluarga

\section{SISTEM BUDAYA TERHADAP GIZI}

Gizi salah (Malnutrition) dapat didefenisikan sebagai keadaan sakit atau penyakit yang disebabkan oleh kekurangan relative atau mutlak dan kelebihan satu atau lebih zat-zat makanan esensial yang berguna dalam tubuh manusia.

Menurut MCA-Indonesia (2015), stunting adalah masalah kurang gizi kronis yang disebabkan oleh asupan gizi yang kurang dalam waktu cukup lama akibat pemberian makanan yang tidak sesuai dengan 
kebutuhan gizi. Stunting terjadi mulai janin masih dalam kandungan.Stunting merupakan salah satu masalah gizi yang berdampak buruk terhadap kualitas hidup anak dalam mencapai titik tumbuh kembang yang optimal sesuai potensi genetiknya. Stunting dapat menghambat proses tumbuh kembang pada balita (Kementerian Kesehatan, 2015).

Sementara masalah gizi terjadi di banyak tempat di berbagai daerah di Indonesia, hanya sebagian pihak yang memandangnya sebagai fenomena sosial. Sebagian lain masih menganggap hal ini sebagai fenomena kesehatan semata. Tidak banyak yang menyadari luasnya dimensi masalah gizi dapat meliputi masalah lingkungan dan ketersediaan pangan, pola asuh dan pendidikan, kondisi ekonomi danbudaya.

Faktor budaya memengaruhi siapa yang mendapat asupan makanan, jenis makanan yang didapat dan banyaknya. Sangat mungkin karena kondisi budaya dan kebiasaan ini seseorang mendapatkan asupan makanan lebih sedikit dari yang sebenarnya ia butuhkan. Di Indonesia, sebagian besar masyarakat menganutsistempatriarki.Dalamsistempatriarki,garisketurunandiambildariseorangAyah(laki-laki), status sosial laki - laki lebih tinggi daripada perempuan. Konsekuensinya, ayah lebih sering diutamakan memakan makanan yang telah disajikan oleh Ibu. Sesederhana ayah lah yang paling sering mendapatkan jatah makanan lebih dulu di meja makan. Bahkan, beberapa daerah di Indonesia mengharuskan pemisahan antara makanan yang harus disajikan untuk Ayah dan anggota keluarga yang lain. Kondisi budaya seperti ini turut berkontribusi pada kondisi gizi anak dan ibu hamil didalam keluarga karena semua system keluarga patriarki berhubungan erat dengan ketidak setaraan gender.

Dari gambaran di atas, terlihat betapa kebiasaan makan tidak dapat dilepaskan dari nilai - nilai sosial budaya masyarakat. Sementara kebiasaan makan sangat erat kaitannya dengan upaya pemeliharaan kesehatan dan pencegahan penyakit. Kurangnya asupan gizi akan meningkatkan risiko terkena penyakit infeksi dan berbagai penyakit kronis yang pada gilirannya akan mengurangi produktivitas dalam bekerja dan berkontribusi kepada masyarakat

\section{SOLUSI MASALAH BUDAYA TERHADAP MAKANAN DAN GIZI}

Sebagai sistem budaya, makanan bukan hanya dipandang sebagai hasil organic dengan kualitas biokimia yang secara fisiologis berfungsi untuk mempertahankan hidup.Makanan juga mempunyai makna sosial budaya yang diakui, dianut, dan dibenarkan olehmasyarakat setempat.

Beberapa mitos dan fakta mengenai makanan dan gizi menjadi salah satu factor penghambat dalam proses perbaikan gizi keluarga. Sebagai contoh, ada mitos yangmengatakan bahwa ibu hamil tidak boleh makan ikan karena bayinya bisa bau amis. Didaerah lain ada juga mitos yang melarang anak balita makan telur karena bisa bisulan. "Itu merupakan dua contoh mitos yang keliru karena telor dan ikan justru merupakan sumber makanan dan gizi yang baik untuk ibu hamil dan anak balita".

Solusinya, tak lain persebaran informasi yang merata soal permasalahan gizi.Selain itu, pemberian pemahaman yang benar tentang asupan gizi yang tepat bagi ibu hamil dan balita. Singkatnya, perlu didorong pengembangan pemahaman budaya makanyang tepat bagi tumbuh kembang balita. Tujuannya: demi mengiki budaya dan mitos yang dianggap mengganggu upaya perbaikan gizi masyarakat. Akar masalah dan solusi sudah ditemukan. Siapa yang memulai langkahnyata? Pemerintah, industry farmasi, pakar medis dan tenaga kesehatan, LSM, dan masyarakat umum, harus berjalan seiring nan sinergis. Betapapun hal ini tak semudah membalik telapak tangan. Sebab, jika tidak demikian, risikonya tak mainmain: Indonesia terancam kehilangan satu generasi karena masalah gizi buruk di masa mendatang.Upayaupaya yang dapat 
dilakukan untuk meningkatkan status gizi masyarakat dalam kaitannya dengan ketersediaan pangan dan pola konsumsi diantaranya:

1. Memperluas lahan pertanian dan sector-sektor lain yang mampu menunjang produksi pangan Indonesia (peternakan,Perikanan)

2. Memperbanyak Jumlah Petani, peternak dan tenaga ahli di bidang pangan dangizi

3. Memperbaiki Pola konsumsimasyarakat

4. Pemerintahharusmampumenyediakanpanganyangbergizidanmudahdijangkau,baiksecara fisik maupuneknomis.

5. Distribusi pangan yangbaik

6. Meningkatkan pengetahuan masyarakat tentanggizi 


\section{DAFTAR PUSTAKA}

La Banudi, Imanuddin, 2017. Sosiologi dan Antropologi Gizi. Forum Ilmiah Kesehatan (FORIKES)

* Ibrahim Anwar Irviani, Syamsul Alam, Andi Syamsiah Adha, Yusma Indah Jayadi, Muhammad Fadlan. 2021. "Hubungan Sosial Budaya Dengan Kejadian Stunting Pada Balita Usia 24-59 Bulan Di Desa Bone-Bone Kecamatan Baraka Kabupaten Enrekang Tahun 2020" dalam Al Gizzai: Public Health Nutrition Journal (hlm. 16-26).

* Kalangi,NicoS.“makanansebagaisuatusystemBudaya:BeberapaPokokPerhatianAntropologiGizi” dalam Koentjaraningrat dan AA Loedin (eds) Ilmu-Ilmu Sosialdalam Pembangunan Kesehatan, Jakarta : PT Gramedia, 1985(42-53). 